\title{
Past Perfect: Jewish Memories of Language and the Politics of Arabic in Mandate Palestine
}

\author{
Liora R. Halperin
}

\section{1 \\ Introduction}

As Zionist institutions in Mandate Palestine discussed and promoted Arabic study in light of increasing Arab resistance to Zionist settlement, ${ }^{1}$ they not only speculated on the origins of this opposition and possible mechanisms of subduing it, ${ }^{2}$ but also crafted nostalgic - and often counterfactual - narratives of past coexistence. For the mainly Yiddish-speaking Jewish settlers arriving in a mainly Arabic-speaking land and seeking to reclaim Hebrew as a vernacular, Arabic offered a pathway to an alternative Jewishness, one rooted in a longlost Semitic identity. While these 'new' Jews worked to contain or suppress the local resistance to their settlement, Arabic became a symbol of a lost, harmonious past when Jews and Arabs did indeed coexist as fellow speakers of Arabic. In this chapter I hope to show that claims during the Mandate period about early Jewish settlers' use of Arabic allowed descendants of the early Jewish agricultural colonies (moshavot, sing. moshava) to craft an image of themselves as the bridge between pre-Zionist and Zionist Jewish Palestine and symbols of a non-political Zionism that transcended conflict - this at a time when all evidence pointed to an increasingly conflictual and provocative role for Zionism in Palestine.

As scholars have noted in their works on nationalism and memory, rhetoric about the past - in this case about past language practices - serves political

1 Growing Palestinian animosity toward Zionism in the twentieth century can be attributed to several factors, including regional and geopolitical ones, but a consensus is emerging that the very separation practices of the Second Aliyah, those whose promoters thought would lessen animosity, in fact exacerbated it because of the tendency of these practices to dispossess Palestinians without offering them a place in the newly configured labour market, see Gershon Shafir, Land, Labor and the Origins of the Israeli-Palestinian Conflict 1882-1914 (Berkeley: University of California Press, 1996); Anita Shapira, ha-Ma'avak ha-nikhzav: 'avodah Tvrit 1929-1939 (Tel Aviv: Tel Aviv University; Ha-Kibbutz Ha-Me’uhad, 1977).

2 On competing rationales for Arabic language study during the mandate period see Abigail Jacobson and Moshe Naor, Oriental Neighbors: Middle Eastern Jews and Arabs in Mandatory Palestine (Waltham, Massachusetts: Brandeis, 2016). 
purposes during times of ethnic rivalry and internecine conflict. ${ }^{3}$ Like discussions about language choices elsewhere in the Middle East during the same period, some of which are discussed in this volume, Zionist settler claims about knowing and deploying Arabic were political. They became part of a larger programme to justify settlement, minimize the significance of resistance, and negotiate internal Zionist divisions at a time of growing partisan acrimony.

European Jewish agricultural settlement in Palestine had begun in the late nineteenth century, when a tiny religious Jewish community, both Sephardi and Ashkenazi, already lived in a handful of Palestine's cities alongside Christian and Muslim Arabs. Jews from the Arab Levant, some of them Sephardic speakers of Ladino, were commonly fluent in Arabic. Religious Ashkenazim, of Eastern and Central European origin, were less likely to formally learn Arabic, but they, too, often knew colloquial Arabic. Many Arabic elements even made their way into their Palestinian Yiddish. ${ }^{4}$ As Menachem Klein argues, "There was no mental boundary separating Muslim and Jew" in Late Ottoman Jerusalem. "The walls of language and culture were low ones, and Jews and Arabs who entered the physical or linguistic zone of the Other felt no sense of being alien." ${ }^{5}$ Some Ashkenazi Jerusalemite families studied Arabic more formally: Reuven Rivlin, grandfather of Israel's current President, studied for a year in an Islamic school and his son Josef went on to research Islamic Studies at the Hebrew University and translate the Qur'an into Hebrew. ${ }^{6}$

European Jewish rural settlers, who began to purchase small plots of land in the late 1870 s, were motivated by visions of making Jews more economically productive through agriculture. They founded twenty-odd colonies in the last quarter of the nineteenth century, including Petah Tikva (1878); Rishon LeZion, Zikhron Yaakov, and Rosh Pinna (all 1882); and Rehovot (1890). Over time, they celebrated their communities as representing a clean break from Palestine's past and the beginnings of a new nationalist project; following World War I this wave of settlement was deemed the "First Aliyah" or first wave of Zionist settlement. ${ }^{7}$ In practice, however, such discourses of rupture

3 Kristin Ross, May '68 and Its Afterlives (Chicago: University of Chicago Press, 2002), 1; Matt K. Matsuda, The Memory of the Modern (New York; Oxford: Oxford University Press, 1996), 15; Michel-Rolph Trouillot, Silencing the Past: Power and the Production of History (Boston: Beacon Press, 1995), 6.

4 Mordecai Kosover, Arabic Elements in Palestinian Yiddish: The Old Ashkenazic Jewish Community in Palestine, Its History and Its Language (Jerusalem: R. Mass, 1966).

5 Menachem Klein, Lives in Common: Arabs and Jews in Jerusalem, Jaffa and Hebron (London: Hurst \& Company, 2014, 2014), 45.

6 Klein, Lives in Common, 42-43.

7 Hizky Shoham, "From 'Great History' to 'Small History': The Genesis of the Zionist Periodization," Israel Studies 18,1 (2013): 31-55. 
obscured real continuities between early settlers and the existing Jewish communities of Palestine. ${ }^{8}$ Petah Tikva and Rosh Pinna's initial founders came from the religious communities of Jerusalem and Safed, respectively, and early settlers in Petah Tikva such as Yehuda Raab and Avraham Shapira learned Arabic while living in Jerusalem. Later arrivals remained reliant on existing Jewish-Muslim-Christian urban networks and Jewish multilingualism to negotiate land purchases and acquire goods and services. The 'break from the past' that became the legacy of the first colonies in the minds of Zionists and Palestinians alike was a retrospective construction. At the time, this settlement occurred and survived only because of Jews who remained imbedded in a preZionist social context.

Within the colonies themselves, which Yuval Ben-Bassat and others have called "proto-Zionist" rather than Zionist per se, ${ }^{9}$ Jewish settlers adopted economic arrangements that made limited use of Arabic necessary. Striving to engage in productive agriculture, first in cereal grains and later in wine grapes and citriculture, colonists regularly hired Arab field labourers at a low wage. ${ }^{10}$ These practices exposed them to the criticism of later arriving Jews, especially those motivated by socialist Zionism and the idea of Jewish-Arab market separation, people who asserted that all economies built on the backs of native labour would be rife with exploitation. Nonetheless, early colonies, many of which came under the foreign Jewish philanthropic support of the Rothschild family, continued hiring Arab field labourers, guards, and drivers throughout the Mandate period. These relationships, though hierarchical and often abusive, nonetheless seemed to suggest a period "prior to conflict" when read selectively and against the intensified conflict of the twentieth century.

In what follows I look at commemorative sources produced in these Jewish colonies during the Mandate period alongside other texts from within the internal Jewish discourses on Arabic in Palestine. Claims about early Arabic knowledge among Ashkenazi Jews had questionable validity as historical generalizations, but they served an important political purpose on the local level. By constructing and appropriating a history of Arabic-speaking European Jewish founders, colony leaders claimed their own legitimacy in the face of political marginalization and put forward a premise, popular particularly among Zionist business interests and the political centre-right, that economic

8 Israel Bartal, "Al ha-rishoniyut: zeman u-makom ba-'aliyah ha-rishonah," in Lesoheah tarbut 'im ha-'aliyah ha-rishonah, ed. Yaffa Berlovitz and Yosef Lang (Tel Aviv: Ha-Kibbutz Ha-Me'uhad, 2010), 15-24.

9 Yuval Ben-Bassat, "Proto-Zionist - Arab Encounters in Late Nineteenth-Century Palestine: Socioregional Dimensions," Journal of Palestine Studies 38,2 (2009): 42-63. 
integration, albeit on strict hierarchical ethnic lines, provided a better recipe for Jewish-Arab coexistence than economic or geographic separation.

\section{The Politics of Arabic in Mandate Palestine}

By the time the British assumed their Mandate over Palestine in 1923, the Jewish community was already politically organized, with ideologically aligned parties, a variety of associated social service organizations, labour unions, and a Jewish city: Tel Aviv. The Yishuv, the common term at the time for the Jewish community, found itself increasingly divided around assessments of the Jewish-Arab conflict in Palestine, its origins, the likelihood of its resolution, and the utility of personal outreach versus military preparedness in addressing it. Ashkenazi Zionists approached these questions from a stance of alienation and foreignness, whereas Sephardi and Oriental Zionists (who are not the subject of this article) discussed the centrality of Arabic as a tool for conflict resolution within the framework of Zionism, as Abigail Jacobson and Moshe Naor have shown. ${ }^{11}$

Arabic language could serve a range of Jewish agendas in this fraught context. As Hillel Cohen has shown, over the course of the Mandate period Zionist organizations sought Arab collaborators and informers. ${ }^{12}$ A variety of labouroriented organizations, from the mainstream socialist Mapai (Jewish Workers Party of Palestine) to the Marxist Ha-Shomer Ha-Tsa ir (Young Guard), came to feel over the course of the Mandate period that reaching out to Arab workers was essential. At a Mapai assembly in 1943, a member named Y. Burstein noted that "our politics in the Arab field is personal politics ... Relations with Arabs determine the solution to the problem." Others at this gathering affirmed the premise that long-term coexistence was possible and could be accomplished by building goodwill through language study. ${ }^{13}$ Members of Ha-Shomer Ha-Tsa'ir also increasingly lamented their lack of Arabic knowledge. A writer in the newspaper of Kibbutz Kfar Masaryk, an agricultural collective (kibbutz) affiliated with the movement, lamented in 1936, "We have not even begun to learn

\footnotetext{
11 Jacobson and Naor, Oriental Neighbors.

12 Hillel Cohen, Army of Shadows: Palestinian Collaboration with Zionism, 1917-1948 (Berkeley: University of California Press, 2008).

13 "From the Words of the Members in the Assembly of Members at the Party's Jerusalem Branch," 4 September 1943. On the Agenda: Activity of the Party in Researching the Arab Problem, 1, BB, 2-926-1943-1, (Arab Division, the Committee for Studying and Clarifying the Arab problem, incoming and outgoing correspondence). Speaker: Y. Burstein. All translations are mine unless otherwise noted.
} 
the ABCs of approaching Arabs." ${ }^{14}$ Over the course of the 1930s and 1940s, and in some cases earlier, some movement newspapers started publishing columns to help Jews learn the language. ${ }^{15}$ Kfar Masaryk, along with other kibbutzim, instituted language courses. ${ }^{16}$ In 1940, a group of Arabists within Ha-Shomer Ha-Tsa'ir gathered to found a Department of Arab Activities intended to teach Arabic and organize workers in the Arab community. ${ }^{17}$

Many of these early twentieth century promoters of "Hebrew Labour," their term for an ideological refusal to hire Arab workers in Jewish-run enterprises, had spent their first weeks or months in Palestine as workers in the citrus orchards or wineries of Petah Tikva, Rehovot, or Rishon LeZion, the three most prominent late-nineteenth century colonies, and had broken away after concluding that the landowners were bourgeois, exploited Arab labour, and were not committed to the national project. They felt that a socialist-inspired program of Jewish-only labour was more conducive to the goal of Jewish mass immigration and national revival. ${ }^{18}$ The vanguards of this group, known retrospectively as the Second Aliyah (immigration wave) began a pitched battle for Hebrew Labour, full of insults at their landowning employers. ${ }^{19}$

Having personally seen instances of denigration and abuse in the colonies, Labour Zionists, as they came to be known, had presumed that economic separation would eliminate exploitation from the Zionist program and win back Arab support for the national settlement project. Some of the colony landowners, in resisting local Zionist Labour organizing, had become allied with the anti-Labour political forces that eventually coalesced into Vladimir Jabotinsky's Revisionist movement, the core of the Zionist right wing. Revisionists, who were defined as much by their harder line militaristic ethos as by their support for private capital, were not known for their investment in

14 Kibbutz Masaryk, Ba-Kibbutz, May 1936, 1.

15 Ba-ma'aleh: 'iton ha-no'ar ha-'oved, 27 January 1933. Yad Ya'ari Archive, Giv'at Haviva.

16 Kibbutz Masaryk, Ba-Kibbutz, May 1936, 10, Yad Ya'ari Archive, Giv'at Haviva.

17 Joel Beinin, "Knowing Your Enemy, Knowing Your Ally: The Arabists of Hashomer Hatsa'ir (MAPAM)," Social Text, no. 28 (1 January 1991): 108, https://doi.org/10.2307/466379. Both Cohen and his Bentov wrote memoirs which provide insights into their upbringing and involvement with Ha-Shomer Ha-Tsa'ir. See Mordekhai Bentov, Yamim mesaprim: zikhronot meha-me'ah ha-mukhra'at (Tel Aviv: Sifriyat Po'alim, 1984); Aharon Cohen, Gufrishon, guf shelishi (Tel Aviv: Ha-Kibbutz Ha-Artzi, 1990).

18 For an account of this experience from a Labour Zionist perspective see Shlomo Zemach, Sipur hayai (Jerusalem: Devir, 1983), 44-45.

19 Zeev Tsahor, "Ha-mifgash ben ha-ikarim le-fo'ale ha-'aliyah ha-sheniyah be-Fetah Tikvah," Katedrah 10 (January 1979): 142-50; Moredecai Reicher, 6o shanah le-hakhrazat ha-herem al po'alei Petah Tikva: Hanukah tarsa"v-hanukah tashka"v (Petah Tikva: Beit Neta; Merkaz le-toldot kibush ha-'avodah ve-yeda' histadruti mi-yesodam shel ha-merkaz ha-hakla'i u-mo'etset po'ale Petah Tikva, 1965). 
Arabic study for purposes of reconciliation. They considered attempts at reconciliation short-sighted and employed Arabic almost entirely for the purpose of intelligence gathering and reconnaissance. ${ }^{20}$ It was easy enough, therefore, for Labour Zionists to look at the capitalist farmers in the agricultural colonies and presume that they were and had always been opponents of building working relationships through language. But some in the colonies were interested in promoting a different narrative of the past.

\section{The Politics of the Past}

By all accounts, the First Aliyah colonies, founded and initially inhabited by Jewish landowners with roots in the Russian or Austro-Hungarian empires and supported by cheap native labour and private capital, were places of labour exploitation and strained relations rather than Jewish-Arab camaraderie. These were places in which Jews and Arabs encountered each other on a daily basis, as the former purchased from and employed the latter and, as a consequence, acquired a limited, instrumental knowledge of Arabic. ${ }^{21}$ Recounting his visit to the Zionist agricultural colonies of Palestine in 1914, the Yiddish writer Yehoash (Solomon Blumgarten) called the lack of Arabic knowledge he had found among immigrant Jews "one of the weakest points of the settlement." Arabic was a language Jews used to address employees, he had found, not a language of conversation: "Colonists who have been living in Palestine for decades know only sufficient Arabic to converse with their Arab Arabaji, or wagon driver. As to writing and reading Arabic, that is out of the question."22 Although there had been various attempts to teach Arabic in the colonies, including hiring a teacher in Rishon LeZion, new immigrants rarely improved. ${ }^{23}$ Scholars have suggested that ignorance of the Arabic language contributed to local suspicions of Jewish settlements at the time. ${ }^{24}$

20 These efforts in the mandate period laid the foundation for some of the IDF intelligence operations after 1948. See Gil Eyal, The Disenchantment of the Orient: Expertise in Arab Affairs and the Israeli State (Stanford, CA: Stanford University Press, 2006).

21 Early records suggest that whole communities of labourers in the Rehovot colony lived in or near the colony together with their families. There was regular economic interaction, moreover, with local Arab villages that would sell produce to the colonists.

22 Yehoash, The Feet of the Messenger (Ayer Publishing, 1977), 194; Yehoash, Fun New York biz Rehovos un tsurik (New York: Hebrew Publishing Company, 1919), 44.

23 Yaacov Ro'i, "Yahase yehudim-'arvim be-moshvot ha-'aliyah ha-rishonah," in Sefer ha'aliyah ha-rishonah, vol. 1 (Jerusalem: Yad Yitzhak Ben-Zvi, 1982), 252.

24 Yosef Gorny maintains that the colonies should not, in and of themselves, have provoked Arab opposition, because their number was small, "but it was the subjective interpretation, coloured by the convictions and emotions of the fellahin, that influenced relations 
Even those sympathetic to the overall colony model of employing low-wage Arab Labour sometimes suggested the need for additional commitment to Arabic among settlers. During the year of the Yehoash's visit, the citriculturalist and writer Moshe Smilansky had also spoken critically of immigrant Jews, saying that "Over the course of thirty years we did not learn the language of the land. In the entire Hebrew Yishuv there are not even ten people who can read and write Arabic. This fact might seem absurd to the reader; but to our disgrace, this is the reality." 25 For him, the circumstances themselves demanded better knowledge of Arabic; what needed to change, he felt, was not the economic arrangements but Jews' recognition of their obligations within them.

For Labour Zionist ideologues, however, language and labour issues were related. Ha-Shomer (The Guard), a Jewish guard organization founded in 1909, saw Jewish-only guarding (also known as "Hebrew guarding") as the first step in a broader program of economic separation: where colonies conventionally hired Arab, Circassian, and Maghrebi (North African) men to guard the colonies and their property, Ha-Shomer suggested that this practice exposed the colonies to theft by the guards or their friends and, more broadly, led to passivity and weakness. Alongside its posture of muscular Jewish self-defence, Ha-Shomer also prided itself on a new commitment to Arabic language knowledge, a commitment they emphasized and valorised in Mandate-era commemorative books. Such books, though written years after the fact, are a useful primary source in understanding their retrospective self-construction during the Mandate period. ${ }^{26}$

In her retrospective essay about her role in the formation of Ha-Shomer, Manya Shohat asked rhetorically "How would a small group of Jews live among masses of Arabs educated in the tradition of the desert, the rifle and the knife,

with the settlers." In addition to lack of Arabic knowledge he cites cultural differences, especially around the status of women. Yosef Gorny, Zionism and the Arabs, 1882-1948: A Study of Ideology (Oxford [Oxfordshire]: New York: Clarendon Press; Oxford University Press, 1987), 17-19. Yehuda Slutzky in Sefer Toldot Ha-Haganah suggests that lack of Arabic knowledge led to the first attack on Petah Tikva.

25 Moshe Smilansky, "Ba-moledet," Ha-'Olam, 16 January 1914, 6. Smilansky also criticised the denigrating attitude of Zionist colonists in Palestine, claiming that prior to their immigration they had considered the land "as an abandoned wasteland waiting for its redeemer and had not revised their views even after coming to Palestine and finding that it was not a virgin landscape."

26 Gur Alroey notes that the absence of contemporary materials from Ha-Shomer has produced a historiography that tends to repeat the organization's auto-hagiography. He turns to documents from the agricultural colonies to challenge assertions about their pre-wwI activities. I view the Mandate era commemorative volumes as a primary source in their own right - about mandate-era concerns. Gur Alroey, "Mesharte ha-moshavah o rodanim gase ruah?: me'ah shanah le-agudat ha-shomer, perspektivah historit," Katedrah 13 (2009): 77-104. 
whose ethics are totally different from ours?" Her answer to this classical colonial conundrum was based on language: the guard program pushed Jews "to learn the Arabic language, the customs and concepts of the Arabs, because for the project to succeed it was necessary to create neighbourly relations based on mutual respect and in accordance with the people's psychology and its traditions." ${ }^{27}$ Voices like Shohat's became dominant in Zionist and Israeli historiography, and a discourse on teaching Arabic from a position of economic separation came to seem normative. ${ }^{28}$ Ha-Shomer rarely acknowledged the tension at the heart of its endeavour: by striving for closeness from a position of national separation, the Hebrew Labour ethos rendered Arabic knowledge among Jews even weaker than before.

But even Ha-Shomer members, who considered themselves heirs to a lineage of ancient Jewish defenders such as the Maccabees, ${ }^{29}$ also found model defenders in the "First Aliyah" colonies, their former employers, while denigrating these communities as a whole. "The isolated, the daring, who went out in front," wrote Manya's husband Yisrael Shohat, won the respect of Arabs, but in general Arabs denigrated Jews both in the city and in the village, "because they thought of them as weak and cowardly." ${ }^{30}$ The heroes of the First Aliyah period and their escapades defending against a variety of local attacks were to occupy a similarly ambivalent place in the narrative provided by The History of the Haganah, a multi-volume Labour Zionist text about the evolution of Jewish militarism. ${ }^{31}$

Some of the Mandate-era leaders of the Labour movement acknowledged that the Hebrew Labour programme had reduced opportunities for more natural language acquisition. In a 1942 memo to Moshe Shertok (Sharett), head of the Political Department of the Jewish Agency and later the second Prime Minister of Israel, Miriam Glickson commented that

Today there is a lack of direct contact between Jews and Arabs such as existed in the first settlements [the colonies]. Then there were Arabs in

27 Manya Shohat-Vilbushevitz, "Ha-shemirah ba-arets" [Guarding in the Land] Kovets Ha-Shomer: Te'udot, zichronot u-divre ha'arakhah [The 'Ha-Shomer' Collection: Documents, Memories, and Appreciations], Tel Aviv: Arkhiyon ha-Avodah, 1936-7, 51.

28 On the central place of Arabic in the self-image and culture of the Labour Zionist movement, see Oz Almog, The Sabra: The Creation of the New Jew (Berkeley: University of California Press, 2000), 198-200.

29 Yael Zerubavel, Recovered Roots: Collective Memory and the Making of Israeli National Tradition (Chicago: University of Chicago Press, 1995), 17.

30 Yisrael Shohat, "Shelihut ve-derekh," in Sefer ha-Shomer: divre haverim, ed. Yitzhak Ben-Zvi et al. (Tel Aviv: Devir, 1957), 4.

31 Shaul Avigur and Ben Zion Dinur, eds., Toldot ha-Haganah, Mahadurat 'Am 'oved, vol. A pt. 1, ha-Sifriyah ha-Tsiyonit (Tel Aviv: Ma'arakhot, 1954), 93-104. 
every house and community and every resident knew how to conduct a conversation with them. But today the settlements are separate, most of their residents don't know Arabic at all and the work of spreading the language is only beginning. On the other hand, thanks to systematic study (an important thing that was lacking in the early settlements) we imparted to some of the residents an elementary knowledge of the literary language, of the Arab question, and of Arab folkways. ${ }^{32}$

Though she and Shertok advocated economic and residential separation from Arabs, Glickson appears to be bemoaning the loss of Jewish-Arab contact that had occurred in the early Jewish agricultural colonies. Labour Zionists did not explicitly swear off interethnic contact; they believed that close labour cooperation could occur within the proletariats of both peoples. However, they thought that this cooperation could only occur following a Jewish "conquest of labour." 33 Nonetheless, the imagined product of the bygone Jewish-Arabic contact - Arabic knowledge among Ashkenazi Jews - had declined such an extent that by 1942 the Jewish Agency felt that more "systematic" instruction by trained European Jewish Orientalists was necessary. ${ }^{34}$

Some Labour Zionist leaders recognized the contradiction inherent in promoting closeness through separation. At a 1944 gathering of Jews to discuss the state of language learning programs, Michael Assaf, active in Mapai and the labour union it dominated (the Histadrut), noted that "Our community was not built on the idea of mixed settlements [of Jews and Arabs] and [this explains] the little real Arabic knowledge among our members ... in fact, in the colonies, whose spirit is more chauvinist, there is a more positive approach to Arabic, given that there is vital contact with the Arabs in practice." ${ }^{35}$ Such statements acknowledge the flaws of the axiomatic association between Labour Zionist ideology and lived Jewish-Arabic interaction.

32 Memo from Miriam Glickson to Moshe Shertok, re: conference of Arabic teachers in the communities, (which took place on 25-26 August 1942), 3 September 1942, CZA, J17/322. The conference included the heads of the Department of Education as well as candidates for teaching in the communities.

Zachary Lockman, Comrades and Enemies: Arab and Jewish Workers in Palestine, 1906-1948 (Berkeley: University of California Press, 1996), 47-110.

34 On the evolution of Arabic language study in Israel, especially around the defense establishment, see Eyal, The Disenchantment of the Orient; Mendel, The Creation of Israeli Arabic. Both suggest that the military sphere came to dominate Arab studies in the Jewish community of Palestine and Israel so much that the only non-native speaker students who achieved proficiency in the language were those who expected a military career. Many writers have lamented the poor state of Arabic language studies among Israeli Jews. Protocol mi-fegishat muzmanim be-she'elat hora'at ha-'Arvit, 13 July 1944, Yad Ya'ari Archive (Givat Haviva) (2)4.21.95, Eliezer Be'eri, Personal, Correspondence, 1941-1952. 
The colonists themselves highlighted these contacts. Members of an economically powerful but often politically side-lined class of agriculturalists during the Mandate period, they emphasized their own status as firsts and founders and promoted a narrative of Zionist settlement that they suggested was implicitly superior to the socialist Zionist vision that politically displaced them. During the Mandate period, they both asserted their own political relevance and promoted a model of Jewish-Arab relations that they claimed was pragmatic, moderate, and rooted in the realities of the market.

Local historiography from the "First Aliyah" colonies, conveyed in anniversary volumes, memoirs, pedagogic texts, and agriculturalist journals, abound in narratives about Jewish-Arab (and Ashkenazi-Sephardi) contacts that are taken to demonstrate colonists' commitment to coexistence based in economic hierarchy. ${ }^{36}$ These Mandate-era texts were part of a broader program of commemorating the past and asserting its significance in the face of opposition and Labour Zionist dominance, in part through a focus on heroic types known for their combination of Arabic knowledge and masculine bravery. ${ }^{37}$

Zerubavel Haviv, a Russian Jew of Ashkenazi origin and son of one of the founders of Rishon LeZion, established in 1882 southeast of Jaffa, called on fellow Zionists in 1946 to renew their commitment to Arabic language instruction in schools. "Knowledge of the language of our neighbours is an elementary obligation," Haviv wrote, "and shared lives will not be possible in this land and in the vicinity without a common language."38

Haviv had no affiliation with the Labour Zionists who set up programs for mutual understanding and institutes for the study of Arabic. ${ }^{39}$ Not only does

36 Two key organization of successors were the Farmers' Federation (Hitahdut ha-Ikarim), founded in 1929 which advocated the interests of capitalist farmers, and Bene Binyamin, an organization run by children of the first planters that was instrumental in founding new colonies, including Netanya and Herzliya, in the 1920s. Both had trouble articulating a political message or determining whether to position themselves as a political organization at all. Neomi Shiloah, Merkaz holekh ve-ne'elam: ha-hugim ha-ezrahiyim beErets Yisra'el bi-shenot ha-sheloshim (Jerusalem: Yad Yitzhak Ben-Zvi, 2003), 77-88; Yigal Drori, Ben yamin li-semol: ha-hugim ha-ezrahiyim bi-shenot ha-ésrim (Tel-Aviv: Mif'alim universita'im la-hotsa'ah la-or, 1990), 162-79.

Yosef Lang, "Sefarim ve-yovlot: Petah Tikva mitmodedet 'im 'avarah," in Le-Fetah Tikvah (Petah Tikva: Oded Yarkoni Petah Tikva Archive, 2012), 10-50.

38 "Arabic in the vocational high school," 2 July 1946.

39 Abigail Jacobson, "Sephardim, Ashkenazim and the Arab Question in Pre-First World War Palestine: A Reading of Three Zionist Newspapers," Middle Eastern Studies 39, no. 2 (2003): 105-30; Michelle U. Campos, "Between 'Beloved Ottomania' and 'The Land of Israel': the Struggle over Ottomanism and Zionism among Palestine's Sephardi Jews, 1908-1913," International Journal of Middle East Studies 37, no. 4 (2005): 461-83; Beinin, "Knowing Your Enemy, Knowing Your Ally"; Zachary Lockman, Comrades and Enemies: Arab and Jewish Workers in Palestine, 1906-1948. 
Haviv criticise the Labour-Zionist economic and political agenda that became dominant in the Yishuv after World War I, he also felt that Labour Zionists systematically and unfairly overlooked the achievements and successes of their non-labourite predecessors, those like his father. Haviv was not content to let Labour Zionists claim the mantle of caring about Arabic study without recognizing a much older Zionist commitment to the language. Why, he wondered, did later, Labour-leaning arrivals "never [stop to] wonder about the acts of the first settlers [ma'ase rishonim], and think that the entire Hebrew Yishuv [Jewish community] was founded upon their own arrival?"40

Haviv, like others from the late nineteenth-century Jewish colonies, had built rituals of commemoration around these settlers, constructing them as heroic men cherished for cultivating positive relations with local Arab populations, first and foremost through their knowledge of Arabic. Some of these individuals gained fame through their untimely deaths at the hands of Arabs, others by surviving and serving as living myths. In each narrative their knowledge of Arabic, always acquired through personal contact rather than through formal programs or institutes, gave them a familiarity with the landscape and the ability to build trust with locals in a way that made their Jewish colonies resistant to attack and explained the relative paucity and minimal severity of Arab resistance to Zionist settlement as compared to trends in the twentieth century. While historians have offered other contextual explanations for this increase in violence and recall the more ethnically mixed pre-Zionist environments with which these settlers remained in contact, Haviv and others were more than pleased to take personal credit for these figures as Zionists and place blame on the backs of groups associated with their political opponents.

Two early colonists, Avraham Yalovsky and Avraham Shapira, both epitomized this seemingly natural acquisition of Arabic. Yalovsky, born in Bialystok in 1850, came to Palestine in 1883 and was a blacksmith in Nes Ziona, located south of Rishon LeZion. He was murdered in his hut in the winter of 1888-9 for unclear reasons. In 1994, during his signing of the Cairo Agreement between Israel and the PLO, Israeli Prime Minister Yitzhak Rabin would refer to him as the first casualty in the Yishuv, a sort of ur-casualty of Zionist memory. ${ }^{41}$ But Yalovsky's commemoration had begun quite a bit earlier, during the Mandate period. Moshe Smilansky, a major participant in the elevation and celebration

40 Zerubavel Haviv, "Ha-'Arvit be-vet ha-sefer ha-'amami" [Arabic in the Primary School] Ha-Boker, 2 July 1946, 2.

41 Yitzhak Rabin, "Alfe kevarim: shelanu ve-shelahem," Speech delivered at the signing of the Cairo agreement between Israel and the PLO, 4 May 1994. http://www.rabincenter.org .il/Items/o1734/3.pdf 
of the first colonies, emphasized that, "Yalovsky learned Arabic and in his nature loved joking and had lively, entertaining conversations and would draw customers both through his talking and through his work." 42 According to Moshe Levanon, a resident of Nes Ziona who shared his memories of Yalovsky in 1926, he lived in a lone house on the periphery of the colony that served as a meeting point: "Often Arab peasants and Bedouin from among his acquaintances [ma'rüfiyya] would meet in his house and he would chat with them about various matters." In Levanon's view, Yalovsky was killed despite his good relations with the peasants who would come to him to have horseshoes made. ${ }^{43}$ Yalovsky combined several characteristics that lend credit to him and by extension to Nes Ziona. He was an entrepreneurial businessman, operating independently and drawing customers through the laws of the market. He was intrepid, willing to set up shop outside the centre of the colony. And he was a jovial man, building personal relations without any connection to organized political movements.

While Yalovsky is known because he died, Avraham Shapira of Petah Tikva was known because he lived. As he was fond of quipping to audiences, "In all the days of my life I never killed anyone and I never was killed." 44 Shapira, born in Southern Ukraine in 1870, became a guard in Petah Tikva in 1890 and died at the age of 95 in 1965 . Over the course of the Mandate period he was praised locally not only for knowing Arabic but also for using these skills to track down stolen items, resolve conflicts between Petah Tikva and neighbouring villages, and even intervene as a judge in conflicts between Arab clans. His Arabic nickname, Sheikh Ibrahim Mikha, was often cited as proof of this alternative identity.

These personal connections with Arab leaders, largely corroborated by evidence from the period, seemed particularly distant during the days of the 1936-1939 Arab revolt. At that point Zionist immigration had increased considerably, as had Palestinian self-awareness as a national group in danger of being sidelined by Zionism. In a 1939 appeal addressed to "Hebrew Youth" and aimed at funding the second of the two volumes of Shapira's memoirs, a fundraising committee made up largely of representatives from the colonies and Zionists outside the Labour movement wrote that "you have of course heard and read of the acts of Avraham Shapira" and suggested that members of the

42 Moshe Smilansky, Perakim be-toldot ha-yishuv. (Tel Aviv: Devir, 1939), Vol I, 80-81.

43 Moshe Levanon, "Lifnei heyot 'Nes Ziona': perek zikhronot." Written 11 Heshvan/ 19 October 1926. Given to Nes Ziona archive by Noam Reiber in 1998, in the name of Yitzhak Levanon. Nes Ziona Archive, Avraham Yalovsky Folder.

44 Dan Ben-Amotz and Hayim Hefer, Yalkut ha-kezavim (Tel Aviv: Ha-Kibbutz Ha-Me'uhad, 1956), 38 . 
community must understand the necessity of publishing his memoirs in order that "the young Hebrew generation learn to walk in his ways." In what way would he serve as a model? In addition to being the "renewed Jewish heroic type," he "aroused respect among the daring [Arab] neighbours." The project, the appeal suggested, would give youngsters the feeling of "the honour of a nation raising heroes in its own land" and would teach them "the laws of relating to the [Arab] neighbours on both sides of the Jordan, both in peace and in conflict, but always with honour."45

Though Shapira was unaffiliated with any political party, he sided more with the right-wing or anti-Labour part of the Zionist political spectrum. Nonetheless, his longevity and identity among the first generation of recognized founders made his reputation seem to transcend politics. In 1946, just after the end of World War II, the Jewish Agency sent Avraham Shapira a greeting on the occasion of his $75^{\text {th }}$ birthday that past December: "His name flutters over many pages of the magnificent review of building and guarding our name and our honour - great was his role in improving friendly neighbourly relations. Proud and upstanding, he knew how to weave the web of good relations between the villages that border our points of settlement." ${ }^{\text {"6 }}$ Wisdom about resolving ongoing national and land conflict, these texts imply, would come not from the Labour leadership but from wisdom acquired by representatives of the founding generation of Zionist (in reality proto-Zionist) land settlers.

As presented in commemorative, retrospective, or advocacy materials produced during the Mandate period, Yalovsky and Shapira learned Arabic through sheer force of will and unmediated connection with locals. But historical circumstances suggest that these narratives obscure two key pieces of relevant context: new immigrants of the late nineteenth century who did achieve near-native fluency did so often through the intermediation of Sephardi and Mizrahi Jews who knew Arabic, or through connections with the pre-Zionist Ashkenazi Jewish communities of Palestine, which tended to have spoken proficiency in Arabic (if not reading knowledge) through daily neighbourhood and commercial contacts. In other words, they had these skills not because they were exemplars of a transformed Jewish type, but because their communities actually remained embedded in pre-Zionist structures. It's not surprising that such evidence is mentioned only occasionally. Those promoting the colonies had been accused by Labour Zionists of insufficient commitment to the nationalist project and excessive diasporic traits of religiosity and affinity

45 Va'ad Ha-yedidim le-hotsa'at zichronot Avraham Shapira, n.d. [1939], Petah Tikva Archive 003.002/12 Item Number 8404.

46 'Ever Hadani (ed.), Me’ah shenot shemirah be-Yisra'el (Tel Aviv: Y. Chechik, 1954), 108. 
for capitalism. They had reasons to minimize these contexts and emphasize personal valour and a break from the past.

One source of linguistic knowledge historically was Arabic-speaking Middle Eastern Jews who came to work in the colonies during their early years. Yehuda Raab recalls in his memoirs that the Petah Tikva colony hired two Oriental Jews, one from Baghdad (Daoud Abu Yusef) and one from Jaffa (Ya'qub Bin Maimun Zirmati), as guards in the early colony. When Abu Yusef arrived in the colony, Raab says, its residents were "still trainees in the ways of the Ishmaelites." But the Baghdadi Jewish guard provided a path out of this situation as soon as he set up a hut for himself in Petah Tikva "he became my teacher and Rabbi in the ways of guarding and neighbourly-relations." ${ }^{\prime 7}$

Abu-Yusef, in representing a world largely (but not fully) alien to Raab's, immediately demonstrates Raab's own ignorance; his texts render Raab illiterate, unable to make out the "strange letters" of the two languages that he claims to know, Hebrew and Arabic. But this intermediary helps him bridge the linguistic gap and allow the representatives of the "First Aliyah" to claim nativeness. Indeed, Haviv cited access to such native figures and willingness to employ him as evidence of this founding generations' commitment to positive Jewish-Arab relations.

A second source of linguistic knowledge came from the new colonies' roots in and connections to the existing Jewish communities of Palestine, especially those of Jaffa, Jerusalem, and Safed. The founders of Petah Tikva were Orthodox Jews from Jerusalem and over time both Jaffa and Jerusalem served as starting points and way stations for later immigrants who would become landowners in the colonies. Historical literature about Jewish land settlement in Palestine tends to obscure these connections, preferring to present the farmers as pioneers (or foreign colonists) wholly unmoored from the older Jewish communities Palestine. But there is evidence to demonstrate these connections. In the memoirs he had transcribed in 1939, Avraham Shapira from Petah Tikva suggested that he learned Arabic in Jerusalem and then Jaffa when his family had just arrived. Amazed at the perceived cowardice of other Jerusalemite Jews, that “turned a person's simple walk on the earth into a source of danger and bravery" the young Shapira imagined himself as someone

47 Yehuda Raab, Ha-Telem ha-rishon: zikhronot, 1862-1930 (Jerusalem: Ha-Sifriyah HaTsiyonit 'al-yede ha-Histadrut ha-tsiyonit ha-'olamit, 1988), 68. See also Liora R. Halperin, "Trading Secrets: Constructions and Contexts of Two Middle Eastern Guards in the Early Petah Tikva Agricultural Colony," International Journal of Middle Eastern Studies 51:1 (January 2019): 1-22. 
who could transcend these stereotypes. ${ }^{48}$ Like Jewish modernists of all stripes in Europe and Palestine, he had been fantasizing about such a transformation. While in synagogue on the holiday of Shavuot he dreamt of "Vassily and Ivan fleeing from him just as he and his friends had to flee from them."49 According to Shapira, this transformation into a Jewish version of "Vassily and Ivan," his Russian persecutors, began in earnest in Jaffa. Language, and specifically curses, motivated him: "Yil'an dīnak" (cursed be your religion), "Yahūdī kāfir," (Jewish infidel) and "Shekenāzi Khanazìr" (Ashkenazi pig) but "other than that, [Shapira] didn't understand anything." Remembering the insults of Ukrainians, Shapira claimed to be motivated to learn the language "so he could respond." And, indeed "through this exchange of 'compliments' Avraham came to realize that he knew how to speak Arabic, and within a few months could 'quarrel and play' with them without inhibitions."50

Arabic, which by all accounts Shapira did indeed come to know very well, became central to the narrative of his subsequent interactions and his striking ability to charm, impress, and intimidate the region's Arabs. Shapira's Arabic knowledge was unusual among settlers in the colonies, but less so when we understand him as a product of his Jerusalem origins, derisively called the "Old Yishuv" by those who imagined a rupture caused by nationalist settlement.

\section{$4 \quad$ Conclusions}

The Jewish agricultural colonies established in Palestine in the last two decades of the nineteenth century were tiny and surrounded by Arab villages, which provided most of their early workforce. Although their founders imagined a project targeted exclusively toward Jews and had not systematically considered possible effects on Arab populations, they generally presumed that Jewish-Arab market contact would be an essential part of their project. ${ }^{51}$ Even as conditions changed, as Palestinian resistance to Zionist settlement grew and national conflict loomed large, some of these founders nostalgically and often counterfactually constructed or evoked an image of past coexistence based in language knowledge.

\footnotetext{
48 Yehuda Idelstein, Avraham Shapira (Sheikh Ibrahim Mikhah), vol. 1 (Tel Aviv: Yedidim, 1939), 34 .

49 Idelstein, 1:32.

5o Idelstein, 1:37.

$5^{1}$ Dimitry Shumsky, Beyond the Nation-State: The Zionist Political Imagination from Pinsker to Ben-Gurion (New Haven: Yale University Press, 2018).
} 
This vision, however, was not of equality. It was of what I call hierarchical coexistence, i.e., between an employer and a menial worker. This is not true coexistence but rather a compelling illusion, so compelling that in retrospect advocates of it have become models not only to the capitalist right, but also to the left. One such advocate was Yitzhak Epstein, a Zikhron Yaakov landowner, who in a 1907 essay, "The Hidden Question," argued that colonists could assuage Arab protests through awareness of possible opposition and paternalistic benevolence. Epstein, a Hebrew teacher in Zikhron Yaakov who had immigrated to Palestine in 1886, warned that when Jews purchased land being worked by native Arabs, they left a festering wound in the heart of the peasant. He cautioned that even if Arab workers seemed compliant "as long as the wages were good," they would protest later if they sensed they were going to be removed from the land they held so dear. This protest, however, could be mollified if Jews committed to purchasing fallow lands, allowed Arabs to remain on land that they were working at the time of purchase, and instructed these peasants in modern farming practices. ${ }^{52}$

Epstein is often regarded as one of the few early Zionists to recognize the ethical and national problem of dispossessing Arabs in the course of European Jewish immigration and settlement. Some, therefore, regard him as a spiritual predecessor to those on the Zionist left, as well as those non-statist Zionists who would echo his call for coexistence work during the Mandate period, including bi-nationalist groups such as Brit Shalom. But it is more appropriate to see Epstein's vision of Jewish-Arab coexistence as an early voice in a bourgeois, capitalist coexistence discourse premised on Jewish-Arab hierarchy.

Epstein celebrated the fact that colonies hired Arab workers: "the situation of the [Arab] cities and villages near the colonies has been elevated; many craftsman, stone masons, builders, whitewashers, donkey and camel drivers, and thousands of workers find work in the colonies." ${ }^{53}$ Not only Jewish settlement but also the hiring of low wage Arab labour seemed justified so long as it was accompanied by modernizing and civilizing reforms. Agriculturalists who hired Arab labour and considered it wrongheaded to do otherwise echoed variants of this position in the decades that followed.

The Arabic language sat at the heart of narratives about Jewish-Arab "coexistence," not only those from the Zionist left, whose efforts to study Arabic while promoting labour separation have received the bulk of scholarly addition, but also those criticised for their continual hiring of Arab workers.

$5^{2}$ Yitzhak Epstein, "She'elah ne'elmah," Ha-Shiloah 17 (July-December 1907) Odessa: Ahiasaf, [193-206], 195

53 Ibid., 199. 
Narratives of past language knowledge, during a period of growing political contention, were tools in an unfolding Zionist conversation about the links between language knowledge, conflict, and the possibility of harmony in a situation of European Jewish land settlement.

\section{Bibliography}

Almog, Oz. The Sabra: The Creation of the New Jew. Berkeley: University of California Press, 2000.

Alroey, Gur. "Mesharte ha-moshavah o rodanim gase ruah?: me'ah shanah le-agudat ha-shomer, perspektivah historit." Katedrah 13 (2009): 77-104.

Avigur, Shaul, and Ben Zion Dinur, eds. Toldot ha-Haganah. Mahadurat 'Am 'oved. Vol. A pt. 1. 3v in 8 vols. Sifriyah ha-Tsiyonit. Tel Aviv: Ma'arakhot, 1954.

Bartal, Israel. "Al ha-rishoniyut: zemon u-makom ba-'aliyah ha-rishonah." In Lesoheah tarbut 'im ha-'aliyah ha-rishonah, edited by Yaffa Berlovitz and Yosef Lang, 15-24. Tel Aviv: Ha-Kibbutz Ha-Me'uhad, 2010.

Beinin, Joel. "Knowing Your Enemy, Knowing Your Ally: The Arabists of Hashomer Hatsa'ir (MAPAM)." Social Text 28 (1991): 100-121. https://doi.org/10.2307/466379.

Ben-Amotz, Dan, and Hayim Hefer. Yalkut ha-kezavim. Tel Aviv: Ha-Kibbutz Ha-Me'uhad, 1956.

Ben-Bassat, Yuval. "Proto-Zionist - Arab Encounters in Late Nineteenth-Century Palestine: Socioregional Dimensions." Journal of Palestine Studies 382 (2009): 42-63. https://doi.org/10.1525/jps.2009.38.2.42.

Bentov, Mordekhai. Yamim Mesaprim: Zikhronot Meha-Me’ah Ha-Mukhra'at. Tel Aviv: Sifriyat po'alim, 1984.

Campos, Michelle U. 'Between 'Beloved Ottomania' and 'The Land of Israel': The Struggle over Ottomanism and Zionism among Palestine's Sephardi Jews, 19081913." International Journal of Middle East Studies 37,4 (2005): 461-83.

Cohen, Aharon. Guf Rishon, Guf Shelishi. Tel Aviv: Ha-Kibbutz Ha-Artzi, 1990.

Cohen, Hillel. Army of Shadows: Palestinian Collaboration with Zionism, 1917-1948. Berkeley: University of California Press, 2008.

Drori, Yigal. Ben yamin li-semol: ha-hugim ha-ezrahiyim bi-shenot ha-esrim. Tel-Aviv: Mif'alim universita'im le-hotsa'ah le-or, 1990.

Eyal, Gil. The Disenchantment of the Orient: Expertise in Arab Affairs and the Israeli State. Stanford, CA: Stanford University Press, 2006.

Gorny, Yosef. ha-She'elah ha-Arvit veha-be'ayah ha-Yehudit: zeramim mediniyimIde'ologiyim ba-Tsiyonut be-yahasam el ha-yeshut ha-Arvit be-Erets Yisra'el bashanim 1882-1948. Tel Aviv: 'Am 'Oved, 1985.

Gorny, Yosef.Zionismand the Arabs, 1882-1948:A Study of Ideology. Oxford [Oxfordshire]: New York: Clarendon Press; Oxford University Press, 1987. 
Halperin, Liora R. Babel in Zion:Jews, Nationalism, and Language Diversity in Palestine, 1920-1948. Yale University Press, 2014.

Halperin, Liora R. "Trading Secrets: Constructions and Contexts of Two Middle Eastern Guards in the Early Petah Tikva Agricultural Colony," International Journal of Middle Eastern Studies 51:1 (January 2019): 1-22.

Hadani, 'Ever, ed. Me'ah shenot shemirah be-Yisra'el. Tel Aviv: Y. Chechik, 1954.

Idelstein, Yehuda. Avraham Shapira (Sheikh Ibrahim Mikhah). Vol. 1. 2 vols. Tel Aviv: Yedidim, 1939.

Jacobson, Abigail. "Sephardim, Ashkenazim and the Arab Question in Pre-First World War Palestine: A Reading of Three Zionist Newspapers." Middle Eastern Studies 39,2 (2003): 105-30.

Jacobson, Abigail, and Moshe Naor. Oriental Neighbors: Middle Eastern Jews and Arabs in Mandatory Palestine. Waltham, Massachusetts: Brandeis, 2016.

Klein, Menachem. Lives in Common: Arabs and Jews in Jerusalem, Jaffa and Hebron. London: Hurst \& Company, 2014, 2014.

Kosover, Mordecai. Arabic Elements in Palestinian Yiddish: The Old Ashkenazic Jewish Community in Palestine, Its History and Its Language. Jerusalem: R. Mass, 1966.

Lang, Yosef. "Sefarim ve-yovlot: Petah Tikva mitmodedet 'im 'avarah." In Le-Fetah Tikvah, 10-50. Petah Tikva: Oded Yarkoni Petah Tikva Archive, 2012.

Lockman, Zachary. Comrades and Enemies: Arab and Jewish Workers in Palestine, 19o61948. Berkeley: University of California Press, 1996.

Matsuda, Matt K. The Memory of the Modern. New York; Oxford: Oxford University Press, 1996.

Mendel, Yonatan. The Creation of Israeli Arabic: Political and Security Considerations in the Making of Arabic Language Studies in Israel. Palgrave Studies in Languages at War. Houndmills, Basingstoke, Hampshire; New York: Palgrave Macmillan, 2014.

Myers, David N. Between Jew \& Arab: The Lost Voice of Simon Rawidowicz. Tauber Institute for the Study of European Jewry Series (Unnumbered). Waltham, Mass.: Hanover: Brandeis University Press; Published by University Press of New England, 2008.

Raab, Yehuda. Ha-Telem ha-rishon: zikhronot, 1862-1930. Jerusalem: Ha-Sifriyah Ha-Tsiyonit 'al-yede ha-Histadrut ha-tsiyonit ha-'olamit, 1988.

Reicher, Moredecai. 60 shanah le-hakhrazat ha-herem al po'alei Petah Tikva: Hanukah tarsa"v-Hanukah tashka"v. Petah Tikva: Beit Neta; Merkaz le-toldot kibush ha'avodah ve-yeda' histadruti mi-yesodam shel ha-merkaz ha-hakla'i u-mo'etset po'ale Petah Tikva, 1965 .

Ro'i, Yaacov. "Yahase Yehudim-'Arvim be-moshvot ha-'aliyah ha-rishonah." In Sefer ha'aliyah ha-rishonah 1:245-68. Jerusalem: Yad Yitzhak Ben-Zvi, 1982.

Ross, Kristin. May 1968 and Its Afterlives. Chicago: University of Chicago Press, 2002. Shafir, Gershon. Land, Labor and the Origins of the Israeli-Palestinian Conflict 1882-1914. Berkeley: University of California Press, 1996. 
Shapira, Anita. Ha-Ma'avak ha-nikhzav: 'avodah 'Ivrit 1929-1939. Tel Aviv: Tel Aviv University; Ha-Kibbutz Ha-Me'uhad, 1977.

Shiloah, Neomi. Merkaz holekh ve-ne'elam: ha-hugim ha-ezrahiyim be-Erets Yisra'el bishenot ha-sheloshim. Jerusalem: Yad Yitzhak Ben-Zvi, 2003.

Shoham, Hizky. "From 'Great History' to 'Small History': The Genesis of the Zionist Periodization.” Israel Studies 18,1 (2013): 31-55. https://doi.org/10.2979/ israelstudies.18.1.31.

Shohat, Yisrael. "Shelihut ve-derekh." In Sefer ha-Shomer: divre haverim, edited by Yitzhak Ben-Zvi, Yisrael Shohat, Matti Megged, and Yohanan Tabersky, Tel Aviv: Devir, 1957 .

Shumsky, Dimitry. Beyond the Nation-State: The Zionist Political Imagination from Pinsker to Ben-Gurion. New Haven: Yale University Press, 2018.

Smilansky, Moshe. Perakim be-toldot ha-yishuv. Tel Aviv: Devir, 1943.

Trouillot, Michel-Rolph. Silencing the Past: Power and the Production of History. Boston: Beacon Press, 1995.

Tsahor, Zeev. "Ha-mifgash ben ha-ikarim le-fo'ale ha-'aliyah ha-sheniyah be-Fetah Tikvah." Katedrah 10 (1979): 142-50.

Yehoash. Fun Nyu-York biz Rehovos un tsurik. New York: Hebrew Publishing Company, 1919.

Yehoash. The Feet of the Messenger. Ayer Publishing, 1977.

Zemach, Shlomo. Sipur hayai. Jerusalem: Devir, 1983.

Zerubavel, Yael. Recovered Roots: Collective Memory and the Making of Israeli National Tradition. Chicago: University of Chicago Press, 1995. 